\title{
HEALTH DISORDERS OF THE EMPLOYEES EXPOSED TO ORGANIC SOLVENTS AT WORK
}

\author{
Artūrs Veide*, Maija Eglīte*, Mārìte Ārija Baḳe*, and Elvīra Čurbakova** \\ * Institute of Occupational Safety and Environmental Health, Rĩga Stradinš̌ University, Dzirciema iela 16, Rīga, LV-1007, LATVIA \\ ** Centre of Occupational and Radiological Medicine, Pauls Stradiṇš Clinical University Hospital, Pilsoṇu iela 13, Rīga, LV-1002, LATVIA \\ E-mail: arturs.veide@gmail.com
}

Communicated by Jānis Gardovskis

\begin{abstract}
The aim of the study was to investigate the impact of exposure of organic solvents at work on related health disorders in Latvia. Two surveys were carried out with a total number of 2520 respondents. Retrospective analysis of incidence of occupational diseases caused by organic solvents was performed. $21.4 \%$ of employees indicated absorption of chemical substances through skin. The incidence of occupational diseases caused by organic solvents has a stable trend to decrease from year 2003. 58.8\% of employees believe that their long-term health disorders are related to their work environment or work conditions. While organic solvents remain an essential working risk problem in Latvia, the data on exposed persons and their health disorders caused by organic solvents are not sufficient enough. Biological monitoring could facilitate early diagnostics of non-specific health disorders caused by organic solvents.
\end{abstract}

Key words: exposure to organic solvents, health disorders, occupational diseases.

\section{INTRODUCTION}

Organic solvents are the largest group of chemical substances used in the work environment. In Latvia, controlled emissions by companies in 2002-2004 (particularly in the processing industry) released large amounts of different solvents, both as technical mixtures (white spirits, kerosene), and the so-called combined solvents, including aromatic hydrocarbons (toluene, xylenes), esters (ethyl acetate, butyl acetate), alcohols (butanol, ethanol, isopropanole), ether type compound ethylcelosol and ketones (acetone). Most of the widely used chemical solvents in Latvia are used in furniture and wood article production (lacquering and painting processes) and metal and metal article production (defatting, cleaning and painting of metal surfaces). All oil soluble organic solvents easily absorb through intact skin. Some substances can soften the upper layer of skin (solution of washing soda, solutions of surface-active substances), thus reinforcing the ability of other substances to absorb through skin and penetrate into blood. Since skin participates in the breathing process, gases also can absorb through the skin (Boman and Maibach, 2000; Bake, 2001).

Organic solvents as occupational hazards are associated with work-related acute and chronic health disorders. An acute effect of organic solvents is observed in cases of accidents when occupational safety rules have been violated and the occupational exposure limit value is exceeded by tens of times, and also when these solvents penetrate into the body through the gastrointestinal tract (Eglite, 2000; Dick, 2006).
The specific effect depends on the solvent's chemical activity and the effect caused by its metabolism products. Thus, for example, poisoning with benzene and its homologues can cause disturbances of regulation of the central haematogenic system; in the case of poisoning with hydrocarbon halogen derivatives one can observe liver and kidney damages and body sensibilisation are observed (Eglite, 2000; Triebig and Hallerman, 2001; Dick, 2006).

Besides the specific health disorders, caused by organic solvents, the literature data indicate many other non-specific effects on health: in cases of acute occupational poisoning solvents can affect the body non-specifically, causing disorders of the central nervous system - headache, giddiness, narcotic effect (nearly all volatile, oil soluble organic solvents), which can develop into unconsciousness, cramps and even death. Other non-specific effect can cause skin irritation, conjunctivitis, irritation of pharynx and respiratory tract mucosa because of the defatting action of solvents. During the two last decades, the epidemiological researches have stated a connection between a lasting occupational exposure to organic solvents and non-specific symptoms, such as headache, fatigue, irritability, memory disturbances, reduced intellectual abilities, concentration difficulties, emotional instability, depression, sleep disorders, reduced alcohol tolerance, reduction of libido and potency; lasting occupational exposure to organic solvents affects harmfully normal aging processes (Xiao and Levin, 2000; Nilson et al., 2002). 
Chronic poisoning with organic solvents can occur in persons who for several years have worked in premises with high concentrations of organic solvents, in the air. In cases of chronic poisoning, both the central and peripheral nervous systems are most often affected, along with disorders in other organs and organ systems (Boman and Maibach, 2000; Eglite, 2000; Triebig and Hallerman, 2001; Dick, 2006). Because of the chronic irritating and defatting effect of organic solvents, dermatitis, conjunctivitis and chronic breathing tract inflammations can develop. The irritation features of aromatic organic solvents are more expressed than in aliphatic compounds. Halogen derivatives of organic solvents after a direct contact with skin can cause erythema, ulcers, burns; halogen hydrocarbons have a marked specific hepatotoxic effect and they can cause liver damages. There are data available on the high risk of nonspecified systemic connective tissue damage to workers working with petroleum distillates. Organic solvents have also sensibilising properties (Lacey et al., 1999; Boman and Maibach, 2000; Eglite, 2000; Xiao and Levin, 2000). Tetrachloroethylene, routinely used in dry cleaning, in the occupational environment increases the risk to develop non-Hodgkin's lymphoma, cancer of uterine neck, alimentary tube, bladder and kidneys (Pesh et al., 2000; Lash and Parker, 2001).

The number of occupational diseases caused by organic solvents in Latvia was continuously growing till year 2000, when a three-fold increase compared to previous years was registered (Veide, 2002). No newer data has been analysed. Occupational diseases and health disorders caused by organic solvents can be avoided, providing an adequate prevention and treatment to the persons exposed. Therefore, it is essential that all involved persons (exposed employees, their employers, health and safety specialists and responsible authorities) are aware of the exposure and its potential impact to health. Yet, there are no data on the number of exposed persons to organic solvents in Latvia.

The aim of the study was to investigate the impact of exposure of organic solvents at work to the related health disorders in Latvia. The objectives were to survey employees on their working environment and to analyse the incidence of related occupational diseases.

\section{MATERIALS AND METHODS}

Two separate surveys were carried out in 2006: survey of employees and survey of the self-employed. The total number of respondents was 2520 (2455 employees, 65 self-employed). The types of surveys were: Computer Assisted Personal Interviews (CAPI) at the place of residence of the respondent and specialised ad hoc interviews. A special sub-survey was developed for each group of respondents; however, all questionnaires contained an identical general part. This allowed to analyse occupational risks, work conditions, legal labour relations, awareness and other topics within each group and to compare the results. The following questions were included in the surveys: awareness on work conditions and occupational risks, special aspects of work conditions and occupational risks, work conditions within the respective enterprise, including work time (overtime work, time for work and time for relaxation, reduced work hours), compliance with legal labour relations in the enterprise, conclusion of employment contracts, compliance with occupational health and safety legislation within the enterprise, on site training and instructions, use of individual protective equipment, probable obstacles, problems causing non-compliance with occupational health and safety requirements (economic and legislative problems, lack of knowledge or information), attitude towards occupational safety and its importance within the enterprise, employment contract options available in the labour market (e.g., reduced working hours), representatives of employees regarding occupational health and safety issues (e.g., trusted representatives and/or membership in trade unions) and obstacles etc. Respondents during the inquiry were asked: to what extent are you exposed to chemical substances (vapour, smoke, inhaling of dust or dangerous chemical substances)? They could choose answers in such categories as all the time, nearly all the time; about 3/4 (75\%) of the whole time; about half of the whole time; about $1 / 4(25 \%)$ of the whole working time; nearly never. A similar question was asked also about the absorption of chemical substances through skin. Taking into consideration that one of the most typical properties of organic solvents is their ability to absorb through skin, we can, to a certain extent, attribute the above inquiry data also to organic solvents.

The retrospective analysis of incidence of occupational diseases caused by organic solvents was performed using the data of the Register of Latvian State Occupational Disease Patients at the Occupational and Radiation Medicine Centre of the Pauls Stradiņš Clinical University Hospital. The Register contains information of more than 12000 registered cases of occupational diseases. The registered patients underwent medical examination and regular control of health condition, using clinical, physiological, allergological and immunological methods at outpatient or stationary departments. The final diagnoses of occupational diseases were confirmed by the Consultative Commission in Occupational Diseases, consisting of doctors of the Centre. All diagnoses in the Register are coded according to the existing International Classification of Diseases ICD-10 (Anonymous, 2006). The first-time registered number of occupational diseases caused by organic solvents was analysed. In order to make the results comparable, the incidence was calculated per 1 calendar year / 100000 of the employed in Latvia at the beginning of the year.

\section{RESULTS}

$33.2 \%$ of respondents acknowledged that they did have or had had long-term health disorders, which negatively affected their everyday activities. Most often respondents mentioned chronic musculoskeletal health disorders (upper 
and lower back pain, aching joints) $-17.9 \%$, cardiovascular and pulmonary disorders $-8.8 \%$ and neurological disorders (including headache, bad memory, memory loss, vertigo, arm numbness) $-8.3 \%$. More than a half - a total of $58.8 \%$ respondents believed that these disorders were related to work environment or work conditions, while an additional $6.7 \%$ pointed out that disorders had started after an injury at work. According to the respondent's view, $40.3 \%$ to a certain extent were exposed to chemical substances (vapour, smoke, inhaling of dust or dangerous chemical substances). Regarding absorption of chemical substances through skin, 525 respondents $(21.4 \%$ of the total) replied positively (Fig. 1). Only $1 \%$ of employees indicated exposure time to chemical substances as all the working time,

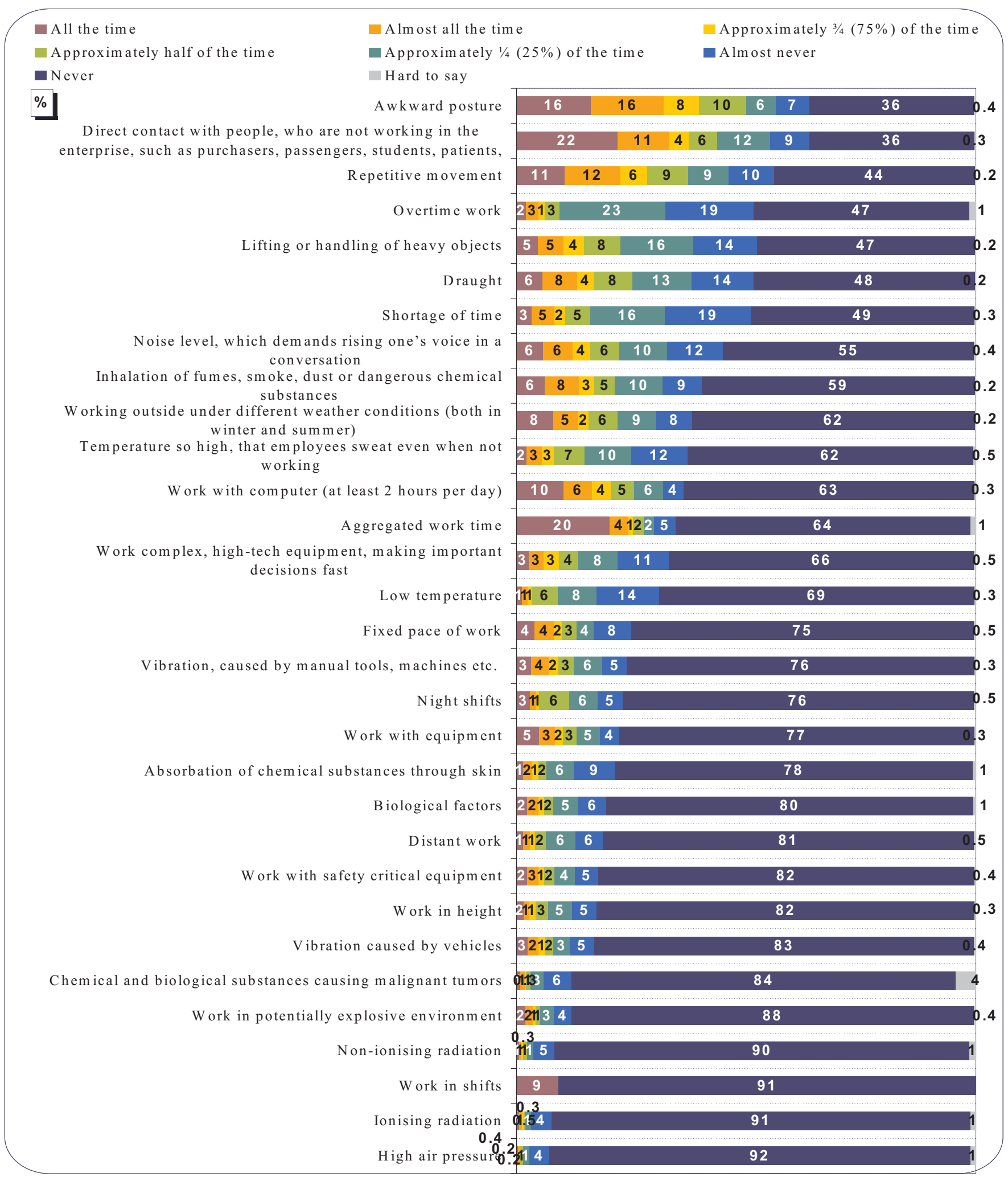

Fig. 1. Exposure of employees to occupational risk factors $(\mathrm{n}=2455)$. 


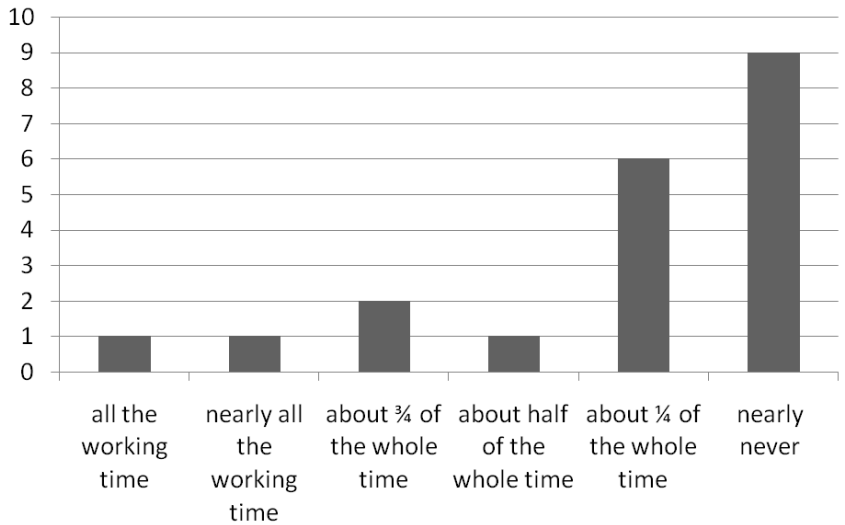

Fig. 2. Absorption of chemical substances through skin (basis: all employees exposed to chemical substances, $\mathrm{n}=2455$ ).

$1 \%$ - nearly all the working time, $2 \%$ - about $3 / 4(75 \%)$ of the whole time, $1 \%$ - about half of the whole time, $6 \%$ - about $1 / 4(25 \%)$ of the whole time, and $9 \%$ - nearly never (Fig. 2). Absorption of chemical substances through skin most often was mentioned in the following sectors: health and social care $(37.2 \%)$, production of metal, metal articles, equipment mechanisms (36.3\%), agriculture, forestry, hunting (31.8\%), construction (29.8\%), processing industry $(26.6 \%)$, production of timber, wood and cork articles, furniture (24.2\%). Men (16.2\%) mentioned absorption through skin more often than women $(8.5 \%)$. No essential difference was observed among respondents of different age groups (18-24 years $-18.1 \%, 25-34$ years $-22.1 \%$, $35-44$ years $-23.2 \%, 45-54$ years $-20.9 \%, 55-74$ years $-21.0 \%$ ), as well as among respondents of different nationalities (Latvians $-21.5 \%$, Russians $-20.6 \%$, others - $23.4 \%$ ). No essential differences were observed also in answers depending on the working place sector: public sector $20.2 \%$, private sector $21.8 \%$, public organisations $21.6 \%)$, as well as depending on company's size (1-9 employees 19.0\%, 10-49 employees 22.7\%, 50-249 employees $19.2 \%, 250$, and more employees $24.7 \%$ ). Similar to many other harmful working environment risk factors, absorption of chemical substances through skin most often was mentioned by respondents who are illegal employees not paying taxes from their salaries (sometimes $26.0 \%$, every month $30.2 \%$ ) than respondents who are legal employees (19.6\%). Slightly more often absorption of chemical substances through skin was mentioned by respondents whose working places are located in villages and rural areas $(25.1 \%)$, than respondents who work in Riga $(20.5 \%)$ or other towns or cities $(20.1 \%)$.

The incidence of occupational diseases caused by organic solvents in the last full year before the survey was 0.3 cases per 100000 employed, with a stable trend to decrease starting from 2003 (Fig. 3). The highest incidence (1.7 cases per 100000 employed) was registered in 1997, 2001, and 2002. The calculated incidence of occupational diseases caused by organic solvents is 3.14 cases per 100000 of the employees exposed to organic solvents at work.

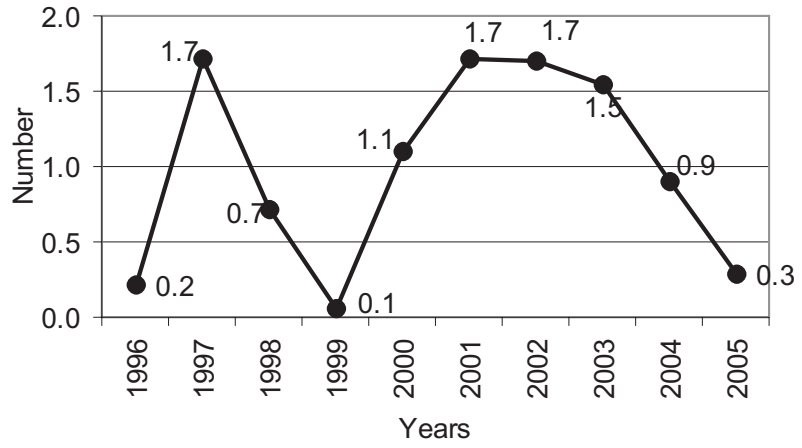

Fig. 3. Breakdown of occupational diseases caused by organic solvents by years (per 100000 employed).

\section{DISCUSSION}

There are no available exact data in Latvia either on the number of workers exposed to organic solvents in the working environment, or on the consequences caused by organic solvents; therefore, this study can give the insight on the actual situation: every fifth employee in Latvia indicated exposure at work to chemical substances which absorb through skin. According to the Central Statistical Bureau and State Revenue Service, the total number of employed people in Latvia in 2005 was 1040 000. Extrapolating from the $21.4 \%$ of respondents who replied positively on absorption of chemical substances through skin, in 2005 the total number of employed persons in Latvia exposed to chemical substances was 223 202, which is 21.38 per 100000 employed. Since this calculation is based on the survey only, to a certain extent it might be subjective. This number is a subject of change according to the economical situation and employment rate. Further investigations in dynamics are necessary to evaluate the correlation of number of exposed employees and registered occupational diseases caused by organic solvents. The objective data from the Register of Latvian State Occupational Disease Patients of the Pauls Stradiņ̌ Clinical University Hospital show that starting from 2003 till year 2006, when the survey took place, there was a continuous decrease of registered occupational diseases caused by organic solvents ( 0.3 cases only per 100000 employed in 2005).

It should be taken in account, that several factors can be mentioned simultaneously as causing occupational diseases. The Register contains data of more than 12000 registered occupational diseases, but does not give sufficient information on other, earlier health disorders before an occupational disease. So it is difficult to properly diagnose without a special attention to exposition factors at work. Biological monitoring can facilitate early diagnostics of health disorders related to organic solvents. The detection of organic solvents in breath is a sensitive method for evolution of occupational exposure in the workplaces (Linnika et al., 2002).

According to the study results, men indicate the exposure twice more than women. This can explain why more men in 
2000 had occupational disease caused by organic solvents. The opposite occurred previously when slightly more woman had occupational disease related to organic solvents (Veide, 2002). The proportion of exposed genders has not been investigated before this study, and therefore, the dynamics is not certain.

Every third employee has or has had long-term health disorders, which negatively affect their everyday activities. The work ability of employees decreases already some time before a chronic disorder is diagnosed, which negatively affects their productivity. It is possible to estimate work ability by calculating work ability index, which shows work ability of a worker at present and in the nearest future, and his/her ability to do his/her work with respect to work demands and according to his/her physical health and mental capacity. Assessment of work ability index was elaborated as a research method by a multi-disciplinary group of experts of the Finnish Institute of Occupational Health (Tuomi et al., 1998). Work ability index is an instrument used in occupational health monitoring to assess capacity of a worker to do the work. This index was applied in Latvia in 1997 and 2000. Now this index was for the third time calculated for people working in health care and social care, and it has not significantly changed during six years. The number of respondents with outstanding work ability has slightly increased (by 3.4\%). The work ability in Latvia is still considerably lower compared to other EU states, especially regarding persons with outstanding work ability (Elsevier et al., 2005; Monteiro and Alexandre, 2009; Tuomi et al., 1998). More than a half of respondents believed that their long-term health disorders were related to the work environment. It is difficult to separate the effect of organic solvents from the effect of other chemical substances. In addition, in the majority of workplaces, different solvents were present simultaneously. Solvents are monodirectional agents, and therefore, the actual impact of a mix of different solvents is higher than indicated by the exposure index assessment for each solvent individually (as it is usually required by the contracting agency - the employer). Occupational hazards cannot only cause specific diseases, but also exacerbate chronic health disorders. The latter are not listed in Latvian legislation; therefore, employees cannot receive compensation for this type of harm.

In conclusion:

1. There was a high number of persons exposed to organic solvents at work, every fifth employee in Latvia indicated exposure at work to chemical substances that absorb through skin. Thus, more attention is required on prevention of health disorders related to organic solvents.

2. The incidence of occupational diseases in 2005 caused by organic solvent is low (0.3 cases per 100000 employed) compared to previous years and has a stable trend to decrease starting from 2003.

3. The obtained results from the Register of Latvian State Occupational Disease Patients show the dynamics of occu- pational diseases caused by organic solvents in Latvia, but cannot represent all consequences caused by the effect of organic solvent on the worker's body, especially nonspecific and early symptoms.

4. Work ability in Latvia is considerably lower compared to other EU states, which is mainly due to harmful work environment. Most of employees believe that these disorders are related to work environment.

5. The structure of gender with occupational diseases caused by organic solvents has been changed; up until 2000, slightly more woman had occupational disease related to organic solvents.

6. A lasting occupational exposure to organic solvents causes many non-specific symptoms, which are difficult to diagnose as occupational. Biological monitoring can facilitate early diagnostics of health disorders caused by organic solvents. A sensitive biological monitoring method is the detection of organic solvents in breath.

7. While organic solvents remain an essential work risk problem in Latvia, the data on consequences caused by organic solvents before occupational disease are not sufficient. There is a lack of information about persons having health disorders than occupational disease. Further investigations are necessary.

\section{ACKNOWLEDGEMENTS}

The surveys were carried out in collaboration with TNS Latvia Ltd. in the frame of the Project "Studies of the Ministry of Welfare" of the National Programme "Labour Market Studies" financed by the European Structural Fund.

\section{REFERENCES}

Anonymous (2006). International Statistical Classification of Diseases and Related Health Problems 10th Revision. WHO. http://apps.who.int/classifications/apps/icd/icd10online/

Baķe, M.Ā. (2001). Svarīgākie veselībai kaitīgo organisko vielu pārstāvji [The most important organic substances harmful to health]. Grām: Darba vides riska faktori un strādājošo veselības aizsardzība (183.-198. lpp). Kaḷkis, V., Roja, Ž. (red.). Rīga: Elpa. (in Latvian).

Baķe, M.Ā. (2001). Ceḷi ķīmisko vielu nokḷūšanai organismā un toksikokinētika [Ways how chemical substances get in the organism, and toxicokinetics] (206.-212. lpp.). Darba vides riska faktori un strāāajošo veselības aizsardzība. Kaḷkis, V., Roja, Ž. (red.). Rīga: Elpa. (in Latvian).

Bake, M.A., Linnika, Z, Rusakova, N, Matisane, L, Veide, A, (2001). Health risk assessment to perchlorethylene during dry cleaning. In: Proceedings of 21th International Symposium "Industrial Toxicology' 2001, Bratislava, May 30 -June 1 (pp. 45-48). Bratislava.

Boman, A., Maibach, H.I. (2000). Influence of evaporation and solvent mixtures on the absorption of toluene and $\mathrm{n}$-butanol in human skin in vitro. Ann. Occup. Hyg., 44, 125-135.

Dick, F.D. (2006). Solvent neurotoxicity. Occup. Environ. Med., 63, 221-226.

Eglīte, M. (2000). Kīmisko faktoru izraisīiā arodpatoloǵija [Professional pathology caused by chemical factors]. Grām: Darba medicina (136.-352. lpp.). Rīga (in Latvian). 
Elsevier, G., Goedhard, W.J.A., Ilmarinen, J. (2005). Assessment and promotion of work ability, health and well-being of ageing workers. International Congress Series 1280, pp. 1-435.

Lacey, J.V., Garabrant, D.H., Laing, T.J., Gillespie, B.W., Mayes, M.D., Cooper, B.C., Schottenfeld, D. (1999). Petroleum distillate solvents as risk factors for undifferentiated connective tissue disease (UCTD). Amer. J. Epidemiol., 149, 761-770.

Lash, L.H., Parker, J.C. (2001). Hepatic and renal toxicities associated with perchloroethylene. Pharmacol. Rev., 53, 177-208.

Linnika, Z., Baḳe, M., Rusakova, N., Veide, A. (2002). Kīmisko tīrītavu darba vide un ar to saistītās problēmas [Work environment of drycleaner's and the associated problems]. Grām.: AML/RSU Medicinnas nozares zinātniskas konferences tēzes (74. lpp.). Rīga (in Latvian).

Linnika, Z., Bake, M.A., Veide, A. (2002). The detection of organic solvents in breath - sensitive method for evolution of occupational exposure in the workplaces. In: Proceedings of the 2nd International Symposium of Occupational Exposure, Occupational Health 21: Quo vadis, Estonia? Tartu, January (p. 19). Tartu.

Monteiro, M.S., Alexandre, N.M. (2009). Work ability and low back pain among workers from a public health institution. Rev. Gaucha Enferm., 30(2), 297-302.

Nilson, L.N., Sällsten, G., Hagberg, S., Bäckman, L., Barregård, L. (2002). Influence of solvent exposure and aging on cognitive functioning: An 18 year follow up of formerly exposed floor layers and their controls. Occup. Environ. Med., 59, 49-55.
Pesch, B., Haerting, J., Ranft, U., Klimpel, A., Oelschlagel, B., Schill, W. (2000). Occupational risk factors for urothelial carcinoma: Agent-specific results form a case-control study in Germany. Int. J. Epidemiol., 29, 238-247.

Tuomi, K., Ilmarinen, J., Jahkola, A., Katajarinne, L., Tulkki, A. (1998). Work Ability Index. Helsinki: Finnish Institute of Occupational Health. $34 \mathrm{pp}$.

Triebig, G., Hallermann, J. (2001). Survey of solvent related chronic encephalopathy as an occupational disease in European countries. Occup. Environ. Med., 58, 575-581.

Veide, A. (2002a). Retrospective analysis of occupational diseases of woman exposed to organic solvents in Latvia between 1985 and 2000. In: 3rd International Congress Women, Work and Health, Stockholm, June 2-5 (p. 316). Stockholm.

Veide, A. (2002b). Organisko šķīinātāju izraisītu arodslimību analīze Latvijā [Analysis of professional diseases caused by organic solvents]. Grām.: RSU Zinātniskie raksti/Medicīnas nozares pētnieciskā darba publikācijas (131.-133. 1pp). Rīga (in Latvian).

Veide A. (2002c). Retrospective analysis of occupational diseases of workers exposed to organic solvents in Latvia between 1985 and 2000. In: Proceedings of the 2nd International Symposium of Occupational Exposure, Occupational Health 21: Quo vadis, Estonia? Taru, January (p. 9). Tartu.

Veide, A., Bake, M.A., Linnika, Z. (2002). Assessment of health disorders among exposed to organic solvents in dry cleaning. In: 3rd International Congress Women, Work and Health, Stockholm, June 2-5 (pp. 316-317). Stockholm.

Xiao, J.Q., Levin, S.M. (2000). The diagnosis and management of solvent-related disorders. Amer. J. Ind. Med., 37, 44-61.

Received 26 June 2009

\section{VESELĪBAS TRAUCĒJUMI NODARBINĀTAJIEM AR ORGANISKO ŠKĪDINĀTĀJU EKSPOZĪCIJU DARBA VIDĒ}

Pētījumā veiktas divas nodarbināto aptaujas ar kopējo respondentu skaitu 2520. Tika veikta organisko škīininātāju izraisītu arodslimību retrospektīva analīze. 21,4\% aptaujāto darbinieku norādīja ḳīmisku vielu absorbciju caur ādu darba vietā. Organisko škīdinātāju izraisītu arodslimību sastopamībai ir stabila tendence samazināties, sākot no 2003. gada. 58,8\% respondentu uzskata, ka vinu ilgtermiṇa veselības traucējumu iemesls ir kaitīgi darba apstākḷi. Lai arī organiskie šḳīinnātāji ir nozīmīgs darba vides riska faktors, informācija par eksponētajām personām un viṇu organisko šḳīdinātāju izraisītajiem veselības traucējumiem nav pietiekama. Organisko škịidinātāju izraisītu nespecifisko veselības traucējumu agrīnu diagnostiku varētu uzlabot ar bioloğisko monitorēšanu. 